УДК 821.112.2-2.09

Н.В. Білоус

\title{
КОНЦЕПЦІЯ ГАРМОНІЇ У ПЕЙЗАЖНІЙ ЛІРИЦІ АННЕТТИ ФОН ДРОСТЕ-ГЮЛЬСХОФ (ЦИКЛ «DIE HEIDEBILDER»)
}

\section{Вступ}

У німецькій літературі творчість Аннети фон Дросте-Гюльсхоф (Annette von Droste Hülshoff, 1797-1848) виділяється яскравою самобутністю. Відзначеній неповторною індивідуальністю творчого почерку, Дросте, як жодному іншому майстру слова свого часу, вдалося виразити велич духовних шукань емансипованої особистості, вимогливої до себе, вихованої на високих класичних зразках поезії Німеччини. Нині іï творчість вшанована включенням до антологій кращих німецьких авторів ХІХ ст., втім, привертає до себе увагу та обставина, що в Україні поетичний спадок видатної німецької поетеси маловідомий не тільки широкому колу читачів, а й спеціалістам-філологам і перекладачам.

Зарубіжні (Ібель, 1960, Гезельгаус, 1943, Борхмейєр, 2003) та російські літературознавці (Рудницький, 1977, Гугнін, 2002, Дмітрієв, 1984) присвятили спеціальні праці аналізу творчості «видатної німецької ліричної поетеси, сповненої сердечної сили, відзначеної печаткою народу Вестфалії, проникнутої враженнями похмурого рідного ландшафту, феодально-католицького світосприйняття та глибокої релігійності» (Вильперт, 1988: 161). Проте наукові висновки щодо поетичної творчості Аннети фон Дросте-Гюльсхоф у сучасному літературознавстві проблематичні й не можуть вважатися остаточними. Тому вважаємо, що картина світу майстрині ще потребує детального вивчення: дискусійним видаються застосування біографічного та інституційного підходів до вивчення літературної спадщини майстрині, віднесення Дросте до певного літературного напряму тощо.

(C) Н.В. Білоус, 2020

http://dx.doi.org/10.34142/2312-1076.2020.2.96.02 
I на початку письменницької роботи, і під час всього свого довгого творчого шляху авторка щиро цікавилася думкою знаних авторів і літераторів (А. Шлютера, А. Шприкмана, Катарини БушШюкинг, Левіна Шюкинга та ін.), зверталася до найбільш актуальних тогочасних тенденцій поезії, випробувала десятки літературних прийомів, змінювала свій стиль у відповідності до власного світовідчуття, поступово розділяючи з читачем свої все більш зрілі й виважені роздуми, але так і не залишила світові жодної збірки, яка була б написана в типовій для романтизму, клерикальної лірики або бідермейєру манері.

Дросте пов'язували з бідермейсром, пізнім романтизмом, раннім реалізмом, поетичним реалізмом, раннім імпресіонізмом (Бакалов, 2003). Літературознавці (Розен, 1993, Мумбауер, 2017) відносять іiі поетичну спадщину до романтизму, але слід зазначити, що лірика поетеси, сповнена романтичних символів та античних метафор, хоча й містить підвищений емоційний тон завдяки численним зверненням до читача, завжди спирається на деталі, що спрямовують увагу не на нервову напругу самовираження чи індивідуальне почуття в образах ліричних героїв, а на контекстні посилання, ідею, яка в творчості Дросте неодмінно містить мудрість усвідомлення реальності й бажання іiї вдосконалити.

У своїй монографії «Die Frau in der Literatur. Der Beitrag der Frau zum literarischen Leben in der ersten Hälfte des 19. Jahrhunderts» Г. Грубек (2008: 76) зазначає, що Дросте починає писати вірші за часів романтизму, проте їх важко співвіднести з певною літературною епохою. Й. Клаассен (1883) зараховує майстриню до романтизму, втім характеризує твори Дросте як такі, що є принципово відмінними від доробку романтиків Німеччини і $\epsilon$, скоріше, спорідненими 3 англійським романтизмом. Клаассен спирається на думку самої авторки, яка вважає себе нездатною проникнутися романтичною манерою письма, адже «не лише мало іiї любить, але й зовсім для неї безталанна» (1883: 76). І все ж він робить висновок, що Дросте мала з романтизмом більше спільного, ніж сама здогадувалася, через те, що і її душа, і характер, як у кожного справжнього поета, були сповнені романтичними почуттями (Клаасен, 1883). 
Вітчизняний учений I. Качуровський (2008: 378) також відносив Дросте до романтиків, адже саме романтизм відкрив підсвідоме для літератури. Втім, оцінюючи творчу спадщину Дросте, ми не повністю поділяємо точку зору I. Качуровського: на відміну від романтичних персонажів ліричні герої Дросте позбавлені душевного захвату, тому що ідеалізація природи і поклоніння їй, так само як і блукання в нереальному світі, їм не властиві. Поетеса переосмислює традиції романтизму: яким би заманливим не був ілюзорний світ у іiі віршах, він містить фізично відчутну загрозу (холод, лід, темрява) i не в змозі утримувати ліричного героя, який робить вибір на користь реальності.

Деякі літературознавці й біографи вбачають у творчості Дросте ознаки раннього реалізму XIX ст.: відомий германіст Ріхард Брінкманн (1969) вважає, що авторці притаманна реалістична творча манера. Реалізм від початку свого формування відзначався такими рисами, як споглядальність, іронічність, опозиційність, критичність, скептицизм, сатирична спрямованість. Дросте не властиві відверта демонстрація політичних уподобань або критичний погляд на сучасні їй суспільні події. Більш того, вона часто використовує широко відомі міфологічні образи й мотиви, що менш властиво літературним творам реалістів.

Метою представленого дослідження $є$ вивчення комплексу поетичних засобів та прийомів у віршах 3 циклу Дросте «Die Heidebilder», за допомогою яких майстриня створює багатопланову ідилічну картину, водночас рухому і збалансовану з точки зору перспективи, з чітким розподілом уваги між дійовими особами та мовцями. Завданнями даної статті $є$ вивчення наступних аспектів: лексико-семантичних засобів, персоніфікації елементів певного пейзажу, використання фольклорних та християнських символів, перехресного представлення одних і тих же персонажів у декількох віршах циклу 3 різної фокальної перспективи для посилення ідеологічної цілісності циклу. 
28 Наукові записки ХНПУ ім. Г.С. Сковороди. Літературознавство, 2020, вип. 2(96)

\section{Методологія і методи дослідження}

Під час роботи застосовано семантико-стилістичний та порівняльний методи, а також контекстуальний інтерпретаційний аналіз поетичного тексту.

\section{Результати та дискусії}

Цикл «Die Heidebilder» був створений Дросте у лютому-березні 1842 року «у єдиному пориві», як сама поетеса пізніше писала Шюкінгу (Дросте, 1842) - вісім віршів даного циклу були представлені на одному i тому ж робочому манускрипті. Цикл, названий «Степовими картинами», поєднав у собі образи, навіяні природою Мюнстерланду - узбережжями Емсу, рівнинами і невисокими пагорбами сьогоднішнього Північного Рейну-Вестфалії (який і зараз залишається переважно сільським регіоном) - 3 фантазією поетеси на теми одухотворення природи й існування містичних істот.

Цикл об’єднаний широкою панорамою пейзажів Вестфалії, представлених з близької перспективи. Високий ступінь деталізації концентрує увагу читача на одній окремій місцевості та на ії зв'язку 3 містичними істотами краю. Представлені образи поетеса докладно розглядає у взаємозв'язку живого й абіотичного, сприймаючи прекрасну картину природи як близьку, рідну, не ідеалізовану, і саме тому - довершену.

У циклі низка віршів об’єднана однією темою: «Der Weiher» / «Ставок». Від імені уявного «я» поетеса змальовує умиротворений пейзаж. Чотири вірші 3 даної групи пов'язані між собою місцем діï, сюжет представлений 3 погляду персоніфікованих ліричних та об’єктивованих осіб. Два вірші - «Die Linde» / «Липа» i «Die Wasserfäden» / «Водяні нитки» - написані від першої особи. Ліричними героями тут виступають липа, що росте на березі ставка, і водорості з тієї самої водоймі - водяні нитки, - образ, який привертає увагу читача. У віршах «Das Schilf» / «Очерет» і «Der Weiher» / «Ставок» виникає образно-зорова асоціація з сонячними днями, відблисками сонця на воді, ритмічним погойдуванням дерев.

Якщо порівняти твори 3 циклу «Heidebilder» 3 віршем Ф. Гельдерліна «Die Eichbäume» (1797), що також написаний у 
формі звернення - ліричний герой звертається до дубів як символу волі і сили («fröhlich und frei / радісні та вільні»), - стає очевидним контраст у ставленні ліричного «я» до персоніфікованого об'єкту. У Гельдерліна поєднання з природою $€$ недосяжним через прихильність ліричного героя до людського буття та його любовні стосунки. Заздрість стає причиною його внутрішнього поневолення («erdulden / винести, fesseln / прикувати, die Knechtschaft / кабала»). Віршізвернення Дросте позбавлені як внутрішньої напруги і спротиву, так і пафосного трагізму, який досягається Гельдерліном завдяки гекзаметру, але твори поетеси мають схожу візуальну палітру завдяки великій кількості епітетів, які використовуються для змалювання краси природи. Концептуально два вірші різняться: ліричне «я» Гельдерліна в типово романтичній манері сконцентроване на особистому, на власній романтичній історії, у той час як Дросте залишається вірною абстрагованому баченню поета, наголошуючи на гармонії людини і природи.

Подібну форму звернення має вірш «Die Erlen» Новаліса, написаний у відповідності до типово романтичної концепції гармонії внутрішнього стану героя і природи: «O Erlen, o wachset und blühet / Mit unserer Liebe doch nur / Ich wette, in kurzer Zeit siehet / Man euch als die Höchsten der Flur». У вірші окрім дерев присутні гаряче сонце, сріблястий струмок і вітер, але представлені вони в пестливій манері, почасти властивій фольклорній естетиці: «Das silberne Bächelchen / сріблястий струмочок, ein anderes Pärchen / інша парочка, die Vögelchen / пташечки, goldlockiges Klärchen / золотокоса Кларочка, Herzchen / серденько». Звернення до дерев, пронизане вдячністю за створену ними романтичну атмосферу, доповнено закликом підтримати у майбутньому романтичні почуття. Світлий і сповнений надії вірш Новаліса різниться 3 віршами 3 циклу «Heidebilder» Дросте простотою посилу і однозначністю його висловлення.

$\mathrm{y}$ «Der Weiher» Дросте поєднує зорові та слухові образи в яскравій картині ранішнього ставка, встановлюючи між ними асоціативні зв'язки: «Spiegel / дзеркальна поверхня, Glanz / блиск, horcht / прислухається, Säuseln / шелестіння, flüstre's / шепоче», 
що апелює до чуттєвого світу читача: «Weste küssen / західні вітри цілують, Die Wasserspinne führt den Tanz / Водяний павук веде танець, Schwertlilienkranz am Ufer steht / Вінок ірисів на березі». Ще більшого візуального об'єму образу додає дворазове згадування світла: «іт Morgenlicht» i «auf des Sonnenbildes Glanz» (Дросте, 1844).

Вiрш «Das Schilf» має форму звернення до поетичного обрамлення ставка, змальованого також і у «Der Weiher». Поетеса залишає те саме місце дії, але змінює перспективу і час. Якщо в поезії «Der Weiher» читач бачив водойму і ландшафт зверху, ніби знаходячись над поверхнею ставка, то у «Das Schilf» ставок представлений 3 берега під час полуденної спеки. Природа, наче турботлива мати, прагне гармонії й спокою навколо дрімотного ставка, висловлюючи у своєму зверненні бажання заспокоїти довкілля: «Stille, er schläft! stille, stille! / Тихо, він спить! Тихо, тихо!, Libelle, reg' die Schwingen sacht, / Бабко, обережно воруши крильцями, Daß nicht das Goldgewebe schrille, / Щоб золотисте павутиння не зазвучало пронизливо, Ufergrün, halt gute Wacht / Зелень берега, гарненько неси вахту, Kein Kieselchen laß niederfallen, / Не дозволь впасти жодному камінцю, breit', Ast, dein grünes Tuch / Гілко, простягни свою зелену хустину» (Дросте, 1844). Саме така форма звертань без відповіді вказує на вищість природи як першоджерела для митця, а загальні інтонації вірша - ніжні і рухомі - не перетворюють їх на наказ. Мова віршів циклу сповнена окличних речень, питань і повторів, при цьому у більшості випадків знак оклику вказує не на високу емоційність або підвищення тону голосу мовця (що було б недоречним, зважаючи на статичну атмосферу спокою у міні-циклі «Ставок»), а на внутрішнє підсилення заклику. Поетеса реалізує таким чином прагматику волевиявлення, а не наказу, адже мовці іiі вірша - персоніфіковані мешканці ставка - демонструють приязнь і єдність у загальному бажанні зберегти спокій.

Образи споріднених природних об'єктів яскраві, кожен 3 них позначений притаманною йому деталлю, оживлений дією: «Ein fallend Reis hat ihn bewegt, / Його змусила поворохнутися гілочка, що падає, Das grad zum Nest der Hänfling trug / Яку саме зараз несла 
до гнізда коноплянка». Центральний образ блаженно дрімотного ставка статичний, його найвизначніша дія - ледь поворухнутися від падіння гілочки, його найточніша характеристика: «Er schläft / Він спить, Und über ihn läßt säuselnd wallen / А над ним дозволяє розвіюватися з шелестінням, Das Laubgewölb' der alte Baum / Завісі 3 листя старе дерево» (Дросте, 1844).

Згаданий вище образ дерева у вірші «Die Linde» передає переживання жінки - турботливої, але самотньої. Це уявне «я»лірична героїня, яка достеменно знає, чого шукає і чого ніколи не досягне. Липа, що височіє над ставком, має ширший огляд місцевості, ніж очерет, тому перспектива знову змінюється. Окрім ставка та бабки Дросте залучає до активних осіб сюжету гусінь, водні нитки та людину - поет виступає на одному рівні з образами живої і неживої природи. Активний персонаж - липа - відсторонена від поета й сприймає його як загрозу ідилічній картині: «Sonst wahrlich hätt“ die Raupe ihn erschreckt / Інакше його справді налякала б гусениця, Die ich geschleudert aus dem Blätterhag / Яку я жбурнула з листяної огорожі». Цей пейзажний вірш завершено нотою самотності, безпомічності і розчарування: «Wie mir zum Hohne, der im Sonnenbrande / Наче назло мені, яка в пекучу спеку, Hier einsam niederlechzt vom Uferrande, / Тут самотньо рине вниз з берега ріки», адже байдужий ставок не врятує липу від спеки (Дросте, 1844). У вірші поетеса використовує звернення від першої особи, насичене метафорами та епітетами.

Яскравий автор пізнього німецького романтизму Й. фон Ейхендорф у 1826 році також звернувся до образу липи як до персоніфікованого співрозмовника у вірші «Bei einer Linde»: «Seh ich dich wieder, du geliebter Baum... / Бачу тебе я знову, улюблене дерево». Вірш Ейхендорфа, як і «Die Linde» Дросте, присвячений темі самотності, яка втілена через призму ностальгії й передає біль ліричного героя. Рани поєднують дерево й ліричне «я», втім образ дерева $\epsilon$ антитезою душевного стану героя: викарбуване юнаком на корі липи ім'я його коханої згодом зарубцювалося, а сердечні страждання героя не минають 3 часом. Характерне для пізнього романтизму бачення дисгармонії світу не представлене у віршах 
32 Наукові записки ХНПУ ім. Г.С. Сковороди. Літературознавство, 2020, вип. 2(96)

Дросте: іiі герої й персоніфіковані елементи їхнього оточення прагнуть спокою й балансу, намагаючись зберегти існуючу гармонію.

Вірш «Die Wasserfäden» також написаний від першої особи множини. Оповідь у ньому ведеться від імені водяних ниток, які відгукуються у відповідь на монолог липи. Властиве будь-якій єдності самоусвідомлення підкріплюється зовнішніми характеристиками, що створює гармонійні стосунки оживлених уявою поетеси ниток 3 оточенням. Цей образ грайливий: «Wer uns kennt, der nennt uns lieb und treu / Хто нас знає, називає нас милими і вірними, Welle mag in unserm Schleier kosen / Хвиля любить пеститися у нашій вуалі» (Дросте, 1844).

Зв'язок струменів зі ставком схожий на непрості людські відносини: «des Teiches Blutsverwandte, fest / близький родич ставка, міцно, Нält er all uns an die Brust gepreßt / Тримає він усіх нас, притиснувши до грудей, Und wir bohren unsre feinen Ranken / I ми устромляємо наші тонкі вусики, In das Herz ihm, wie ein liebend Weib, / Йому у серце, як любляча жінка, Dringen Adern gleich durch seinen Leib / Проникають подібно до вен прямо через його тіло». Водні нитки не усвідомлюють болю, який зазнає об'єкт їхніх слів або дій, вони приязні і до реальних, i до міфологічних мешканців ставка: «Und die Karpfenmutter ihre Brut / A мама-короп (ховає) своє потомство, Welle mag in unserm Schleier kosen / Хвиля любить пеститися в нашій вуалі, Uns nur traut die holde Wasserfei / Тільки нам довіряє чарівна водна фея». Контраст підсилюється тим, що загальний тон вірша надзвичайно світлий і радісний: «lieb / милий, treu / вірний, trauen / довіряти, kosen / пестити, Sterne blinken / зірки блискотять, Sonne» / сонце, flüssiger Kristall / «розплавлений кришталь»: поступове заглиблення i «виринання» панорами, яскраві порівняння й численні епітети створюють неперевершену за силою враження динамічну картину квітучої природи, гармонії, єдності природних сил у вигляді містичних персонажів та персоніфікованих об'єктів пейзажу - переливчастих відблисків сонячного світла на поверхні води (Дросте, 1844).

Семантично вірші циклу «Die Heidebilder» згруповані навколо образу художнього полотна. Особливістю низки віршів є їхня мальовничість, яка втілена в деталізованому пейзажі, та барвистість, 
створена завдяки яскравим кольорам: «blaugolden / синьо-золотий, grünes Tuch / зелена хустина». У читача виникають певні асоціації 3 окремими деталями зображення картини природи: «im Morgenlicht / у ранковому світлі, das tief kristall'ne Becken / центр глибокої кришталевої водойми». Так, рядки «Wie grell die Sonne blitzt! / Як яскраво сяє сонце!» («Die Linde») та «Sonne sich in unserm Netz gefangen / Сонце попало у полон нашої сітки» («Die Wasserfäden») надають уявній картині жовтувато-білих відтінків, а завдяки метафорі «auf seinem Wolkenflaum / на своєму хмарному пуху» («Das Schilf») створюється враження, що поверхня кришталево прозорого водоймища віддзеркалює хмаринки i небо, для яких характерні відтінки білого і блакитного (Дросте, 1844).

Картинам, змальованим у вірші «Der Weiher», надає багатоплановості використання християнської символіки в ідилічному пейзажі. У віршах немає прямої вказівки на християнську складову, але ми припускаємо іiі наявність, виходячи з того, що поетеса була смиренною католичкою. Цим зумовлено використання нею біблійного тла і християнських символів у пейзажній ліриці для створення гармонійної картини життя. Багаторазове згадування про світло, його джерело (сонце, віддзеркалення сонця у воді) і властивості жар, яскравість, протиставлення темряві ночі, - має своїм завданням нагадати про те, що світло є символом духовності і могутності бога. Також кришталь $є$ символом віри і чистоти через його схожість із двома основними стихіями життя - повітрям і водою. Вінок ірисів передає страждання Діви Марії, очерет-смиреннежиття віруючих, а конюшина $\epsilon$ християнським символом Трійці. Липа з античних часів вважалася деревом краси і жіночності, а у Біблії згадується як дерево, що давало прихисток Богородиці. У німецькому фольклорі липа вважалася символом сердечності, захищеності та домашнього затишку. Віруючі часто збиралися на молитву саме під цим деревом-пристановищем, декорували стовбур розп'яттями і образами Діви Марії, уквітчаними липовим цвітом. У вірші «Die Linde» персоніфікований образ липи $\epsilon$ прикладом християнського смирення і водночас символом притулку, що рятує від спеки. 
34 Наукові записки ХНПУ ім. Г.С. Сковороди. Літературознавство, 2020, вип. 2(96)

Кольори поетичного циклу Дросте - кармін (червоний), золотий, білий, блакитний - широко використовуються в християнському богослужінні. Тиша навколо ставка, турбота місцевих істот і рослин про спокій ставка, незмінність і розміреність мирного існування $\epsilon$ мрією, втілення якої прагне будь-яка християнська громада.

Пейзажі у віршах, попри пильну увагу поетеси до найдрібніших деталей і відтінків, не є статичними - вони оживають, намагаючись повернутися до первісної гармонійної картини: «Libellen zittern über ihn / Бабки тремтять над ним, Die Wasserspinne führt den Tanz / Водяний павук веде танець» («Der Weiher»), «Ein lindes Säuseln kommt und geht / Ніжний шелест приходить і йде» («Der Weiher»), «Wieget der Vogel seine Flügel / Качає птах крилами» («Das Schilf»), «Welle mag in unserm Schleier kosen / Хвиля любить лащитися в нашій вуалі, Neben uns des Himmels Sterne blinken / Поруч з нами миготять небесні зірки» («Die Wasserfäden»). Життя в розміреному темпі поетеса зображає через дії, що періодично повторюються: качати, мигтіти, а відчуття відсутності будь-яких змін створюється завдяки протиставленню теперішнього часу та умовного способу: «Ich hauch' ihm meines Odems besten Duft / Я дмухну на нього найкращим ароматом мого дихання, Daß er den frommen Schläfer nicht geweckt / Щоб він не розбудив благочестивого сплячого» («Die Linde»). Лише подія, що порушить ідилію, здатна викликати протидію, адже смисловий лейтмотив чотирьох віршів - тиша і спокій (Дросте, 1844).

Асоціативний світ постає 3 метафоричного тла та живиться складними перетинами образів: «еine Bank lehnt sich an meinen Stamm / лава тулиться до мого стовбура» («Die Linde»). Часто використовуються порівняння: «Den Fäden gleich, die, grünlicher Asbest / Подібно до ниток, які, зеленуватий азбест» («Die Linde»), «wie ein schlüpfend Fischlein zieht / I як рибка, ковзаючи, простягає, Sein Schatten durch des Teiches Spiegel / Свою тінь через дзеркало ставка» («Das Schilf»). Метонімія посилює ефект періодичності подій, поєднаної із зовнішньою статикою зображеної у віршах картини: das Gewürm / гусінь, Das hundertfarbig zittert in der Luft / Тремтить (коливається) у повітрі» (Дросте, 1844). 
Поетеса звертається до метафоричного заміщення ознак персоніфікації образів краси природи: «flüssigen Kristall wir trinken / рідкий кришталь ми п'ємо, in unserm Schleier / під вуаллю розуміється хвиля, aus dem Blätterhag / з листяного схилу», густе гілля із огорожею, «auf seinem Wolkenflaum / на своїй пуховій хмарі», віддзеркалення неба у воді порівнюється з пухнастим облаком, а сама водна поверхня - із дзеркалом: «des Teiches Spiegel / дзеркало ставка» (Дросте, 1844). Зіставляючи об'єкти пейзажу, що сповнені стихійної сили (як от вода або хмари) з крихкими предметами, Дросте створює особливий образ вразливої природи, наділяючи іiі амбівалентними характеристиками 3 метою втілення ідеї схожості між природним та людським.

Читач переконується в суперечливих відносинах поетеси 3 природою, що, як і людські взаємини, можуть бути радісними або сумними чи болючими. Але незважаючи ні на що, Дросте впевнена, що турбота і щирість, навіть без взаємності, дарують людині неповторні почуття душевної гармонії і внутрішнього спокою.

\section{Висновки}

Наше дослідження довело, що вірші Дросте пов'язані між собою поетичним місцем дії, яка розгортається навколо блаженно дрімотного ставка. Кожний твір циклу має нове ліричне «я» та написаний від першої особи. Провідними ідеями поетичного циклу, розглянутого в статті, $\epsilon$ :

1) вищість природи як першоджерела,

2) гармонія людини і природи.

Особливістю віршів циклу $\epsilon$ їхня мальовничість, утілена в деталізованому пейзажі, який викликає в читача певні зорові та слухові асоціації. Яскравість порівнянь, метафор i епітетів створює неперевершену за силою враження динамічну картину квітучої природи, безлічі живих істот, що намагаються відновити первісний баланс. Вірші-звернення Дросте позбавлені внутрішньої напруги і спротиву, пафосного трагізму звучання чи любовної ностальгії, притаманних пейзажній ліриці іiі 
36 Наукові записки ХНПУ ім. Г.С. Сковороди. Літературознавство, 2020, вип. 2(96)

сучасників-романтиків. У картині світу Дросте асоціативний світ постає 3 метафоричного тла та живиться складними перетинами образів, щоб піднести на перший план образ вразливої природи у іï амбівалентності, підкреслити схожість між природним та людським тяжінням до гармонії та умиротворення.

У подальших дослідженнях доречним було б вивчення поетичних засобів застосування фоніки в пейзажній ліриці Дросте. Вважаємо, що аналіз обраних прийомів звукопису і метроритмічних особливостей iї віршів допоможе глибше зрозуміти цю вагому частину літературної спадщини поетеси.

\section{Література}

Бакалов, А.С. (2004). Немецุкая послеромантическая лирика (традиции и новаторство). Дис....канд. филолог. наук, Москва.

Гугнин, А.А. (2020). Немецкая литература ХIX века. От романтизма до бидермайера. Статьи, переводы, комментарии, библиография. Вып. 1. Новополоцк: НЦСГИ ИС РАН.

Дмитриев, А.С. (1984). Предисловие. Дмитриев А.С., Беляев Н.Т., Нечепорук Е.И. и др. (ред.). Die Deutsche Lyrik des 19. Jahrhunderts. Немеичкая поэзия XIX века. Москва: Радуга. 29-31.

Качуровський, І. (2008). Променисті сильвети. Лекиії, доповіді, статті, есеї, розвідки. Київ: Видавничий дім «Києво-Могилянська академія».

Рудницький, М. (1977). Annette von Droste-Hülshoff. Іноземна література. № $6.189-191$.

Borchmeyer, D. von. (Ed.). (2003). Annette von Droste-Hülshoff. Darf nur heimlich lösen mein Haar. München.

Brinkmann, R. (1969). Begriffsbestimmung des literarischen Realismus. Darmstadt.

Claassen, J. (1883). Anna Elisabeth Freiin von Droste-Hülshoff. Leben und ausgewählte Dichtungen. Nikosia.

Droste-Hülshoff, von A. Briefe von Annette von Droste-Hülshoff und Levin Schücking. URL: https://www.projekt-gutenberg.org/droste/brdroste/ brdro012.html. (дата звернення: 15.18.2020).

Gedichte, (1973). Die Ausgabe von 1844. Annette von Droste-Hülshoff. Band 1-2, München: Winkler. 
Grubeck, G. (2008). Die Frau in der Literatur. Der Beitrag der Frau zum literarischen Leben in der ersten Hälfte 19. Jahrhunderts. Diplomica Verlag GmbH.

Heselhaus, C. (1943). Annette von Droste-Hülshoff. Die Entdeckung des Seins in der Dichtung des 19. Jahrhunderts. Halle [Saale]: Max Niemeyer.

Ibel, R. (1960). Annette von Droste-Hülshoff: Werke in einem Band. Ausgewählt und mit einem Nachwort versehen von Rudolf Ibel. Hamburg \& Berlin: Deutsche Hausbücherei.

Mumbauer, J. (2017). Die deutsche Dichtung der neuesten Zeit: Erster Band. TP Verone Publishing.

Rosen, R. (1993). Ein Gitter aus Musik und Sprache: Feministische Analysen zu Annette von Droste-Hülshoff. Paderborn: Schoningh.

Wilpert, G. von. (1988). Deutsches Dichterlexion. Biographischbibliographisches Handworterbuch zur deutschen Literaturgeschichte. Stuttgart: Kroner.

\section{References}

Bakalov, A.S. (2004). Nemetskaia posleromantycheskaia lyryka (tradytsyy y novatorstvo). Dys. ... kand. fyloloh. nauk. Moskva [in Russian].

Dmytryev, A.S. (1984). Predyslovye. A.S. Dmytryev, N.T. Beliaev, E.Y. Necheporuk (eds.). Die Deutsche Lyrik des 19. Jahrhunderts=Nemetskaia poэzyia XIX veka Moskva: Raduha. 29-31 [in Russian].

Huhnyn, A.A. (2020). Nemetskaia lyteratura XIX veka. Ot romantyzma do bydermaiera. Staty, perevodbl, kommentaryy, byblyohrafyia. Issue 1. Novopolotsk: NTSSHY YS RAN [in Russian]

Kachurovskyi, I. (2008). Promenysti sylvety. Lektsii, dopovidi, statti, esei, rozvidky. Kyiv: Vydavnychyi dim «Kyievo-Mohylianska akademiia». [in Ukrainian].

Rudnytskyi, M. (1977). Annette von Droste-Hülshoff. Inozemna literatura, 6, 189-191 [in Ukrainian].

Borchmeyer, D. von. (Ed.). (2003). Annette von Droste-Hülshoff. Darf nur heimlich lösen mein Haar. München [auf Deutsch].

Brinkmann, R. (1969). Begriffsbestimmung des literarischen Realismus. Darmstadt [auf Deutsch].

Claassen, J. (1883). Anna Elisabeth Freiin von Droste-Hülshoff. Leben und ausgewählte Dichtungen. Nikosia [auf Deutsch]. 
Droste-Hülshoff, von A. Briefe von Annette von Droste-Hülshoff und Levin Schücking. URL: https://www.projekt-gutenberg.org/droste/brdroste/ brdro012.html. (дата звернення: 15.18.2020) [auf Deutsch].

Gedichte, (1973). Die Ausgabe von 1844. Annette von Droste-Hülshoff. Band 1-2, München Winkler [auf Deutsch].

Grubeck, G. (2008). Die Frau in der Literatur. Der Beitrag der Frau zum literarischen Leben in der ersten Hälfte 19. Jahrhunderts. Diplomica Verlag GmbH [auf Deutsch].

Heselhaus, C. (1943). Annette von Droste-Hülshoff. Die Entdeckung des Seins in der Dichtung des 19. Jahrhunderts. Halle [Saale]: Max Niemeyer. [auf Deutsch].

Ibel, R. (1960). Annette von Droste-Hülshoff: Werke in einem Band. Ausgewählt und mit einem Nachwort versehen von Rudolf Ibel. Hamburg \& Berlin: Deutsche Hausbücherei [auf Deutsch].

Mumbauer, J. (2017). Die deutsche Dichtung der neuesten Zeit: Erster Band. TP Verone Publishing [auf Deutsch].

Rosen, R. (1993). Ein Gitter aus Musik und Sprache: Feministische Analysen zu Annette von Droste-Hülshoff. Paderborn: Schoningh [auf Deutsch]. Wilpert, G.von(1988). Deutsches Dichterlexion. Biographisch-bibliographisches Handworterbuch zur deutschen Literaturgeschichte. Stuttgart: Kroner [auf Deutsch].

\section{Анотація \\ Н.В. Білоус. Концепція гармонії у пейзажній ліриці Аннетти фон Дросте-Гюльсхоф (цикл віршів «Die Heidebilder»)}

Стаття присвячена вивченню засобів і прийомів утілення гармонії і умиротворення у віршах 3 циклу «Die Heidebilder» Аннети фон ДростеГюльсхоф, об’єднаних темою «Der Weiher»: «Die Linde», «Die Wasserfäden», «Das Schilf» та «Der Weiher». Творчість поетеси визначається неповторною індивідуальністю, ій, як жодному іншому майстру слова того часу, вдалося виразити у пейзажній ліриці баланс статичного та динамічного у взаємодії живої та неживої природи. У статті досліджуються лексикосемантичні засоби образної мови циклу, застосування персоніфікації 
елементів пейзажу, використання фольклорних та християнських символів, перехресне представлення одних і тих самих персоніфікованих персонажів 3 різної фокальної перспективи для посилення сюжетної нерозривності циклу. Семантично вірші циклу «Die Heidebilder» угруповані навколо образу художнього полотна. 3 кожним наступним віршем циклу Дросте інтенсифікує асоціативний зв'язок між поетичними образами та зоровими й слуховими уявленнями читача. Яскравість порівнянь i численні епітети створюють динамічну картину гармонії природи. Комбінуючи вищеперелічені засоби і прийоми, майстриня створює багатопланову ідилічну картину, водночас рухому і збалансовану з точки зору перспективи, з чітким розподілом фокусу уваги між дійовими особами. Одним з аспектів дослідження $\epsilon$ порівняння представлених віршів Дросте 3 творами Ф. Гельдерліна «Die Eichbäume», «Die Erlen» Новаліса, та Й. фон Ейхендорфа «Bei einer Linde», написаними в романтичній традиції когерентності внутрішнього емоційного стану героя і зовнішніх ознак об'єкту природи. Вірші-звернення Дросте позбавлені внутрішньої напруги і спротиву, пафосного трагізму, любовної ностальгії, притаманних пейзажній ліриці iii сучасників-романтиків. У віршах Дросте асоціативний світ постає 3 метафоричного тла. Поетеса наголошує на схожості між природним та людським тяжінням до гармонії та умиротворення.

Ключові слова: Аннетте фон Дросте-Гюльсхоф, поетика, природа, гармонія, ліричний образ.

\section{Аннотация}

\section{Н.В. Билоус. Концепция гармонии в пейзажной лирике Аннетты фон Дросте-Гюльсхоф (цикл стихотворений «Die Heidebilder»)}

Статья посвящена изучению средств и приемов воплощения гармонии и умиротворения в стихах из цикла «Die Heidebilder» Аннеты фон Дросте-Гюльсхоф, объединенных темой «Der Weiher»: «Die Linde», «Die Wasserfäden», «Das Schilf» и «DerWeiher». Творчество поэтессы определяется неповторимой индивидуальностью, ей, как никакому другому мастеру слова того времени, удалось выразить в пейзажной лирике баланс статического и динамического во взаимодействии живой и неживой природы. В статье 
исследуются лексико-семантические средства образного языка цикла, способы персонификации элементов пейзажа, фольклорные и христианские символы. Определены перекрестные связи между персонифицированными образами природы в стихотворениях цикла, представленные с помощью различной фокальной перспективы для усиления связности цикла. Семантически стихи цикла «Die Heidebilder» сгруппированы вокруг образа художественного полотна. С каждым следующим стихом Дросте интенсифицирует ассоциативную связь между поэтическими образами и зрительно-слуховыми представлениями читателя. Яркие сравнения и многочисленные эпитеты создают динамическую картину гармонии природы. Комбинируя вышеперечисленные средства и приемы, автор создает многоплановую идиллическую картину, одновременно подвижную и сбалансированную с точки зрения перспективы, с четким распределением фокуса внимания между действующими лицами.

Одним из аспектов исследования является сравнение представленных стихотворений Дросте с произведениями Ф. Гельдерлина «Die Eichbäume», «Die Erlen» Новалиса, и «Bei einer Linde» Й. фон Эйхендорфа, написанными в типично романтической традиции когерентности внутреннего эмоционального состояния героя и внешних признаков объекта природы. Стихи-обращения Дросте лишены внутреннего напряжения и сопротивления, пафосного трагизма и любовной ностальгии, присущих пейзажной лирике ее современников-романтиков. В поэзии Дросте ассоциативный мир возникает из метафорического фона. Поэтесса акцентирует внимание на сходстве между природным и человеческим тяготением к гармонии и умиротворению.

Ключевые слова: Аннетте фон Дросте-Гюльсхоф, поэтика, природа, гармония, лирический образ. 


\section{Abstract \\ N.V. Bilous. The Concept of Harmony in the Landscape Lyric Poetry by Annette von Droste-Hülshoff (the Cycle of Poems «Die Heidebilder»)}

The article deals with the study of means and techniques of harmony and pacification represented in the poems, taken from «Die Heidebilder» by Annete von Droste-Hülshoff, consolidated with «Der Weiher» theme: «Die Linde», «Die Wasserfäden», «Das Schilf» and «Der Weiher». The poetess' legacy is specified with unique personal touch. Like no other author of the19th century Droste managed to represent the balance of static and dynamic interaction of animate and inanimate nature in her landscape lyric poetry. The article researches lexical and semantic means of figurative language in the cycle of poems as well as the use of personification of the elements of particular landscape, the application of folklore and Christian symbols, the cross-representation of the same personified characters in several poems of the cycle from different focal perspective in order to strengthen the ideological continuity of the cycle. The poems of «Die Heidebilder» are semantically grouped around the core motif of a canvas. Droste creates direct associative bond with the visual and auditory image sensitivity of a reader and intensifies it with each poem of the cycle. Illustrative comparisons and numerous attributes create a dynamic picture of animate creatures and personified objects of nature living in harmony. Having combined the above mentioned means and techniques, the poetess creates a multidimensional idyllic picture which perspective is both flexible and balanced and having a clear view of the characters. One of the aspects of the research is to compare the poems by Droste with «Die Eichbäume» by F. Hölderlin, «Die Erlen» by Novalis, and «Beieiner Linde» by J. von Eichendorff, written in the typical romantic tradition of coherence of a character's internal emotional state with external features of natural objects. The poems by Droste are devoid of internal tension and resistance, tragic message, any affectionate yearning, characteristic of the landscape lyric poetry of the Romanticism contemporaries of Droste. The associative world arises from the metaphorical background and emphasizes the similarities between the natural and the human aspiration for harmony and pacification, pertinent to Droste's worldview. 
42 Наукові записки ХНПУ ім. Г.С. Сковороди. Літературознавство, 2020, вип. 2(96)

Keywords: Annette von Droste-Hülshoff, poetic manner, nature, harmony, lyric imagery.

Рукопис статті отримано 7 листопада 2020

Рукопис затверджено до публікаиї̈ 18 грудня 2020

\section{Інформація про автора}

Білоус Наталя Володимирівна - старший викладач кафедри іноземних мов Таврійського державного агротехнологічного університету імені Дмитра Моторного; вул. Богдана Хмельницького, 18, м. Мелітополь, Запорізької обл., 72312, Україна; e-mail: natascha_belous@ukr.net; https:// orcid.org/0000-0003-1038-4629. 